\title{
Civilisations
}

Revue internationale d'anthropologie et de sciences

humaines

40-1 | 1991

L'Asie et le Pacifique

\section{Soviet Options in the Pacific}

\section{Gerald Segal}

\section{Journals}

\section{Electronic version}

URL: http://journals.openedition.org/civilisations/1678

DOI: 10.4000/civilisations. 1678

ISSN: 2032-0442

\section{Publisher}

Institut de sociologie de l'Université Libre de Bruxelles

\section{Printed version}

Date of publication: 1 January 1992

Number of pages: 43-99

ISBN: 2-87263-063-5

ISSN: 0009-8140

\section{Electronic reference}

Gerald Segal, «Soviet Options in the Pacific », Civilisations [Online], 40-1 | 1991, Online since 07 July 2009, connection on 04 May 2019. URL : http://journals.openedition.org/civilisations/1678 ; DOI : 10.4000/civilisations. 1678

\section{(C) Tous droits réservés}




\section{SOVIET OPTIONS IN THE PACIFIC ${ }^{1}$}

Gerald SEGAL

Imagine the Soviet Union's dream of its future position in the Pacific. If Soviet domestic reform proceeds well, if the massive investment plan in the Far East attracts a flood of new immigrants from European Russia, and if the Soviet storehouse of raw materials are exploited and processed, the Soviet Union could conceivably become a major market for other members of the Pacific as well as a major supplier of commodities. Light industrial products from China and the Newly Industrialized Countries (NICs) could vastly improve the quality of life in the Soviet Far East, if the natural regional trade is allowed to flourish in the atmosphere of domestic Soviet reforms and reduced international military tension. Japan could join in multilateral economic ventures with the Communist states of northeast Asia and could also be a primary investor in joint ventures and the special export processing zones in the Soviet Pacific territories. The NICs and the Association of South East Asian Nations (ASEAN) could also buy Soviet commodities and invest in new Soviet projects. Socialist East Asia could be revitalized, and Vietnam, in particular, could begin to undercut the price of Chinese light industrial products. Moscow may even develop new friends among Pacific islanders, if the Soviet Union's international mining and fishing industries grow and prosper. Soviet military power will probably remain strong in the region, but as Japan and China grow more powerful and independent, the Soviet Union will appear less threatening. In addition, if trade and industries flourish, there will be little incentive for any nation to disturb the peace of the Pacific.

While such a scenario may not be possible in the near future, the Soviet Union today is more likely than ever before to 
become a Pacific power. Rapid advancements in the Soviet Pacific during the twenty-first century are doubtful, but important changes in Soviet policy are already underway. Although great changes have not yet been made, reform is taking place. Analyzing these marginal reforms is useful-they reflect the Soviet Union's new priorities in the Pacific.

\section{A. NEW THINKING}

New trends in the Pacific and new Soviet thinking about the region did not begin with Mikhail Gorbachev, although his July 1986 speech in Vladivostok is the predictable starting point for nearly every analysis of Soviet policy in the Pacific during the past several years ${ }^{2}$. It is now abundantly clear that the Soviet Union is indeed thinking more positively about the Pacific, especially about East Asia. Even Andrei Gromyko, notorious as the Soviet foreign minister who ignored the Pacific, indicated a new shift to a Soviet east-oriented strategy in February $1988^{3}$. To a large extent, the Soviet Union is merely reacting belatedly to Pacific thinking that has already been well understood in the capitalist world, and more recently even in China. From the Soviet point of view, the need for changes in its Pacific policy comes from the recognition of at least six major trends.

\section{The Failing Soviet Far East}

A considerable portion of the much-quoted Vladivostok speech was devoted to Gorbachev's most basic problem in the Pacific -- the failure of the Soviet Far East to meet even the faltering pace of the overall Soviet economy. To be understood, the problems of this region must be analyzed in the larger context of determining how a socialist state economy can be reformed.

The implications of reform for Soviet Pacific policy require some elaboration. There was an urgent requirement to reassess 
the Soviet ability to sustain major military spending in an age of declining growth rates. Thus it was necessary to create a breathing space, where, in a style reminiscent of Deng Xiaoping, reform could be shaped and tough choices about resource allocation made. Military spending had to be restrained and international tensions minimized.

In addition, if the Soviet Union were serious about its Pacific potential it would need to divert resources to build an infrastructure in the region or entice foreign investment. To integrate the Soviet Far East into the booming international economy of the Pacific it was necessary to attract people and jobs. Moscow had made some decisions about the Soviet Far East, but Soviet leaders were still a long way from forming a coherent plan.

The Soviets decided to embark on yet another massive investment plan. The August 1987 plan for the Soviet Far East to the year 2000 suggested that up to $\$ 359$ billion would be spent on the region. One of the key failures in the Soviet economy has been the inability to realize its potential in the Pacific. For example, only 2,150 kilometers of the Baikal-Amur Railway's (BAM) total 3,095 kilometers were open to regular traffic in 1988 , and only 12 of the 46 settlements along the line had been completed. The line is not expected to be fully operational for some years to come. Yet even operating at only one quarter capacity, the BAM was still profitable because of the central 400 kilometer sector that was being used constantly ${ }^{4}$.

The planned Soviet economic reforms concentrated mainly on intensive restructuring, which meant concentrating on existing areas of industrial development and drawing on Soviet investment. Yet some aspets of the plan, and most of the ideas developed in 1988 and after, suggested a more maritime orientation that looked outside the Soviet Union for investment 
and even ideas. Oil, natural gas, coal, timber, and fish would be sold as raw materials or as processed commodities, with investment and markets found mainly in the booming Pacific. The Soviet Far East would have an increased population to implement these tasks; to this end, living conditions would be improved and 30 percent of investment would be on infrastructure ${ }^{5}$. In devising this plan, it is not clear that the planners had resolved differences between emphasizing foreign involvement or internal funding 6 . The debate about making the Soviet Far East a more separate zone linked to East Asia or one more strictly controlled from Moscow has deep roots in modern Soviet history. Indeed, the failure to establish a separate zone casts serious doubt on the long-term future of a successful "look-east" policy for the Soviet Union. But the Soviet debate on the best way to develop the Far East, and the new regulations on joint ventures, suggested that the Soviet Far East may well be given greater freedom to pursue its own distinctive policy in the Pacific.

\section{New Chinese Pragmatism}

China's challenge to the Soviet Union used to be perceived in Moscow in ideological and military terms, but the obvious success of new Chinese pragmatism under Deng made the challenge one of reform. China demonstrated that reform of state socialism was possible and that retaining a socialist character while achieving rapid economic gains was also possible. China's opening up to the international capitalist economy, its bold new ventures in special export zones, and the restructuring of economic ideology suggested that socialist economies could obtain major benefits from the capitalist system.

This new Chinese pragmatism also led to a reduced Soviet threat perception and opened the door to improved Sino-Soviet 
relations. Thus possibilities were enhanced for reducing Soviet defense spending, developing greater cross-border economic cooperation, and learning from Chinese reform experiments. China's greater foreign policy independence reduced Soviet fears of a Sino-Japanese-American alliance. With a lowered perception of the Soviet threat fostered by China, the Soviet Union was better able to convince the Pacific states of its peaceful intentions.

\section{The Rise of Japan}

If the rise of a more independent China created a great power triangle, the rise of Japan as an economic superpower created some elements of a great power quadrilateral. The Pacific showed differences from European bipolarity, especially as military conflicts declined and economic power became more important. Although Japan continued to rely on the United States for defense, by the late 1980's under American pressure, Japan's defense spending had become the third highest in the world (after that of the superpowers). As China began to complain that a more independent Japan might also be a militarily stronger Japan, the Soviet Union began to realize that there was some potential for tacit cooperation with China on preventing Japan from becoming a truly great power. After all, the original Sino-Soviet alliance in 1950 had been built on an anti-Japanese and anti-American basis.

However, the rise of Japan, its trade friction with the United States, its search for new markets in Europe, and its greater investment elsewhere in East Asia, all suggested that the implications of a more independent Japan had to be reassessed. The Soviet Union had to determine whether it could contribute to Japanese independence, without recreating the military threats of the 1930s; whether Japan could be enticed into greater cooperation with the Soviet Union as part of this 
independence; and, considering Japan's lax approach to selling high technology, whether the Soviet Union could obtain more from the Japanese than it had from the West Europeans.

\section{The U.S. Pacific Perspective}

Although the Russians reached the Pacific before the Americans and have a longer Pacific coastline that is closer to the key Pacific states of East Asia, the Americans were the first to recognize the economic benefits that could be gained from investments in East Asia. Even in the nineteenth century, Americans spoke of the coming Pacific Century, while the Soviet Union spoke of Asian security. As a Eurasian power, the Soviet Union will always be more likely to think in continental rather than maritime terms.

By the late 1980s, the Soviet Union began to reassess why the United States had been concentrating on the Pacific dimension. Hence Gorbachev's call for a Helsinki-like AsianPacific security scheme and the new east-oriented policy marked by the 1986 Vladivostok initiative. The Soviet Union also recognized that while most of the Pacific was an "American lake", U.S. power in the Pacific was essentially on the decline. Problems within the Australia-New Zealand-United States alliance (ANZUS) and between the United States and some of the Pacific islands, the instability of the Philippines, and unrest in South Korea, all suggested that there were limits to U.S. power. Growing trade friction with Japan and the NICs, coupled with a general U.S. retreat from continental Asia, suggested the Americans were vulnerable and there were new opportunities in this shifting balance of power.

\section{The End of the Third World}

By the late 1980s it had become easy to reject the notion of a North-South divide in the world. The North was divided into 
an eastern and western component, and the South itself was deeply divided. The shock of oil price increases affected many developing states more than developed states. The ensuing debt crisis damaged the reputation and economic prospects of many Latin American developing states and left a small, but increasingly distinct, group of NICs. Most of the successful NICs were in East Asia, and all were U.S. allies of some kind.

The NICs, most of which thrived with a defined command economy and some variant of Confucian meritocratic government, had long been dismissed by the Soviet Union as aberrations and mere outposts of U.S. capitalism. But as China learned from and traded with the NICs, and the contrast to the basket cases of the neighboring socialist states became more apparent, Moscow reassessed the NICs ${ }^{7}$. With growing trade problems between the NICs and the United States, the growth of Japan as an alternative economic pole of power, and the Soviet Union's own less rigid ideological disposition, the Soviets began to think about potential new relationships in the Pacific.

\section{Comrade Basket Case}

The number of Communist states in the Pacific nearly doubled in 1975, and by 1979, the three new additions were Soviet allies. Then, more than at any other time since 1949, revolution and socialism could be seen as triumphant. The idea of a socialist bloc in the Pacific, as in Europe, made more sense. But two main problems existed--first, while China was socialist, it was an enemy. The detente of the early 1980s began to resolve this problem.

Second all other Communist states in the Pacific were experiencing economic difficulties and were falling behind their non-Communist neighbors. The Soviet Union's resource 
constraints and commitments to reform meant that new economic rigor would inevitably be applied to its Pacific comrades. Closer Sino-Soviet relations made the risk of pressuring recalcitrant Communists low. The allies would have no other country to turn to.

\section{B. PRIORITIES}

Thus the Pacific has been a region in great flux. Diversity, success, and flexibility have been key trends. When the Soviet Union decided to reassess its role in the region, it had few obvious choices, despite a recognition that the need for change was urgent. The following sections describe the priorities that have emerged for Moscow and the role the Soviet Union is likely to assume in the remaining 11 years until the Pacific Century.

\section{Minimizing the United States}

The Soviet Union professes to appreciate the U.S. role as a Pacific power as much as the U.S. role in European security plans. In contrast to Europe, where the Soviet Union has a stronger claim for the natural exclusion of the United States, the new recognition of the United States as a vital actor in Pacific security reflects the Soviet trend toward pragmatism. Yet in the Pacific, as in Europe, the Soviet Union would like to minimize American influence without allowing chaotic conditions to ensue. The Soviet Union is also in part, a status quo power and the diminished importance of the superpower balance is likely to mean a reduction in Soviet influence too.

To an important extent, the Soviet Union sees its relationship with the United States in the Pacific as an extension of the global superpower balance. The Soviets tend to stress the Pacific's East Asian element because, apart from the islands and Australia and New Zealand, any other aspect of the 
Pacific only incorporates the American role. Although "thinking Pacific", does have drawbacks in terms of legitimizing the U.S. role, the Soviets show they are not merely trying to score global points by diminishing the United States. By accepting the U.S. presence, Moscow recognizes that many East Asians feel more secure with at least a tacit American security guarantee. These states, especially many in ASEAN, and even Japan and South Korea, will feel comfortable dealing with the Soviet Union only if they know they can rely on countervailing American power. Chinese detente with the Soviet Union also depends to some extent on the presence of American power ${ }^{8}$.

In economic terms, no Pacific observer would ignore the American presence. If the Soviet Union is serious about attracting foreign investment and taking part in the Pacific economic boom, it must recognize the success of American economic hegemony. Yet such recognition is not equivalent to accepting continued hegemony; at a minimum, this hegemony could be diluted through numerous deals with Moscow. The rise of Japan and the NICs, not to mention China, suggests that American hegemony is, in any event, fading and the restructuring of the international order may provide the Soviet Union with an opportunity to break this U.S. hegemony. The Soviet Union must accept U.S. accomplishments but hope that the Soviet Union can offer new opportunities of greater independence for the Pacific states if U.S. power declines.

The possibility of direct U.S.-Soviet agreements in the Pacific does not seem to be a likely priority. Despite some innovative ideas, and previous joint struggles against European colonialism in the Pacific ${ }^{9}$, the U.S.-Soviet relationship remains more global and European-oriented. Soviet and American scientists met at Khabarovsk in August 1987 to discuss cooperation between enterprises on the U.S. and Soviet Pacific coasts, and foreign ministry officials have met to 
discuss Pacific issues. Joint expeditions to the Bering Sea andcentral Pacific took place in 1988 as good will efforts to officially investigate pollution control ${ }^{10}$. In spite of these meetings, the Soviet decision to explore and exploit its maritime mineral zone in the Pacific must be worrying to the United States. The area, east of Hawaii towards Mexico, is in the heart of an important American naval security zone. Not since the early nineteenth century has Russian power extended so close to Pacific North America and presented such a potential challenge to the "American lake"11.

The United States may not be the only or even the most serious threat to Soviet security in the Pacific, but determining what proportion of the global confrontation with the United States takes place in the Pacific is important. The Soviet Union has traditionally felt threatened in the Pacific, if only because it has been forced to concentrate on the primary threat in Europe. When the threat in the Pacific was defined as emanating mainly from the United States and Japan in the 1950s, the Soviet Union had the benefit of China as an ally. But the Sino-Soviet split soon redefined Soviet priorities, and the Chinese were perceived as the main challenge. Until the late 1970s, China was the primary focus of the Soviet military buildup. With SinoSoviet detente came the first reductions in Soviet forces arrayed against China ${ }^{12}$.

The simplistic phrase, the Soviet Far East military buildup, obscures a number of changes that have occurred over the years. While most of the buildup was directed against China until the late 1970s, during the past decade, efforts have focused on the United States and Japan. One of the essential features of the new international politics in the Asian-Pacific region is the military retreat of both superpowers. For the Soviet Union, the retreat has been more recent. The quagmire of Afghanistan and the sink-hole of Vietnam have encouraged the new Soviet 
leadership to reassess its global commitments. After the departure of Admiral Gorshkov and Marshal Grechko, the chief military advocates of flagwaving and long-range power projection, the Soviet armed forces have been pulled back somewhat from their forward positions. Even the Soviet Pacific fleet is spending 25 percent fewer days at sea and the old cry of the expanding Soviet military presence in the Pacific is no longer accurate ${ }^{13}$. By 1988 the number of Soviet strategic submarines in the Pacific were 75 percent of their 1986 peak, the number of non-strategic submarines were 80 percent of their 1984 peak, the number of primary ships were 82 percent of their 1983 peak, and naval combat aircraft were 87 percent of their 1986 peak.

The Soviet armed forces began reexamining their naval strategy, emphasis on protected sea-bastions and long-range naval power even before Gorbachev. Indeed, the emergence of a group of new military leaders with extensive experience in the Far Eastern establishment has apparently brought a new pragmatism into the highest military offices about the use of force in the region ${ }^{14}$.

Contrary to many predictions of an uncontrolled Soviet military buildup, it is now clear that the Soviet Union is as interested in arms control in the Pacific as it is in Europe. The elimination of weapons in the Soviet Far East as part of the Intermediate Nuclear Forces (INF) agreement is a case in point, as is the announcement in December 1988 that 260,000 troops would be cut from Soviet forces in Asia, including 200,000 in the Far Eastern Theater, by the end of 1990. Gorbachev's policy in the Pacific has given arms control a higher priority ${ }^{15}$. Following the INF accord and the far-reaching provisions for verification, Foreign Minister Shevardnadze proposed confidence-building measures in the Pacific following the European model that 
could include inspection of military bases, perhaps even leading to the mutual stand-down of forces ${ }^{16}$.

The swift American dismissal of the Soviet Pacific proposals is not surprising. The United States has a superior military position in the Pacific, then the United States will have to relinquish more than the Soviet Union. The Soviets could use such asymmetries as a propaganda tool with which to embarrass the United States. For example, the United States has complained about the threat posed by the Soviet military presence at Cam Ranh Bay, but would not agree to relinquish U.S. bases in the Philippines if the Soviets gave up Cam Ranh Bay, as proposed by Gorbachev at Krasnoyarsk in September 1988.

A wide range of differences between European and Pacific security do exist, but because the USSR's diplomatic position appears easier to defend on military issues in the Pacific, the Soviet leadership is likely to pursue its rather ludicrous schemes such as a Pacific Helsinki or the application measures similar to those at the Conference on Security and Cooperation in Europe (CSCE). The grandiose thoughts behind such confidencebuilding measures are now a familiar part of the Gorbachev style. Like proposals for Mediterranean security, the ideas are not serious and are reminiscent of the 1950s style of Soviet propaganda gestures, but the Soviet Union is serious in its recognition of the connection between European and Pacific security. Hence the agreement on a global zero in the 1987 INF accord, the decision to sign the Raratonga pact as a means of increasing anti-nuclear pressure within America's alliances, or the December 1988 simultaneous troop cuts in Asia and Europe.

Such global security concepts should be well understood in the West. The notion of trilateralism and increasing European recognition of the importance of the Pacific mean that 
Gorbachev's calls for global security will not be completely alien to Western ears. But if the Soviet Union seriously believes that it can only enhance its Pacific role through Helsinki-like security schemes, then it will forever remain on the sidelines. Just as Helsinki followed a de facto stabilization of the balance of power in Europe, so the absence of any such stabilization in the Pacific rules out a formal accord. The more complex balance of power in the Pacific makes multilateral confidence-building measures, such as the observation of troop maneuvers, mindboggling; there would have to be nearly as many observers as troops being observed.

In the final analysis, the Soviet Union recognizes that the superpower balance is far less relevant in the Pacific than in Europe. Nor is it necessary to negotiate through Washington to reach local states in the Pacific. The United States is useful as merely a mirror for Soviet power--the United States can indicate that the Soviet Union is an acceptable and positive force in the region through summits with the Soviet Union and by allowing the Soviet Union into such multilateral Pacific organizations as the Pacific Economic Cooperation Conference (PECC). As in the European experience, the Soviets are not seeking out the United States as a trading partner or a political ally; the Soviets are awaiting a decline of U.S. influence, as Washington fails to resolve trade and defense disputes with its capitalist allies. Under such conditions, the Soviet Union will launch its main effort; building bridges to the states on the Pacific west rim. After all, the Soviet Union is their immediate neighbor; the United States is not.

\section{Co-opting China}

The tortuous path from war in 1969 to normalized SinoSoviet relations in 1989 has already been well documented ${ }^{17}$. The international balance of power has seen no such major 
change since the original Sino-Soviet split or the normalization of Sino-American relations in the 1970s. In the Sino-Soviet case, healing has occurred in every major dimension of the original split.

In ideological terms, China and the Soviet Union have abandoned name-calling and disparaging remarks about each other's versions of socialism. They now praise each other's bold experiments in reform Communism and exchange advice on how best to modernize an ideology that seems to have exhausted its ideas. Since both countries are still ruled by Communist Parties firmly committed to the Party's leading role, such ideological detente is crucial. Party-to-Party ties will be restored at the May 1989 summit, and Moscow allowed its East European allies to reinstitute such bonds with China several years earlier ${ }^{18}$.

In military terms, both sides have stopped killing each other's troops along the border and local officials regularly meet to resolve disputes. Both sides have withdrawn approximately 80,000 troops in what can be considered farreaching arms control, although no formal agreement has been signed. Tacit confidence-building measures are in operation as Soviet maneuvers are restrained in size and scale ${ }^{19}$. At Vladivostok, Gorbachev made major concessions to China over their disputed river border, and the ensuing frontier demarcation talks have made rapid progress. In December 1988, Gorbachev announced that 200,000 troops would be removed from the Far Easter Theater--some 40 percent of the total proposed cuts--although only 25 percent of Soviet forces are deployed in this area. China was apparently planning to cut an additional 500,000 from its armed forces as a result.

In economic terms, trade was booming despite a downturn in 1987. China had become the Soviet Union's second largest 
trading partner in the Pacific (after Japan) and the Soviet Union had moved up to fifth place among traders with China ${ }^{20}$. China has even opened a distinctive northern door to trade and crossborder relations in the northeast ${ }^{21}$. This barter commerce is always in balance and therefore involves little hard currency and no crippling debts. Soviet technicians have returned to China to help refurbish old plants and build new ones. During 1988 agreements between the two nations covered 30 enterprises ${ }^{22}$. Delegations shuttling across the border to discuss future cooperation are now too numerous to be of special note.

In terms of the attitude towards the United States, both the Soviet Union and China now agree on the need for detente with Washington. Both countries have lost some of their paranoia about the prospects of being out-maneuvered in the great power triangle. Both Moscow and Beijing now exchange reports on their respective relations with the United States, and the Soviet Union took pleasure in December 1987 in giving China a higher level briefing on the Washington summit than China received from the United States ${ }^{23}$.

In terms of conflict in the developing world, both sides regard the United States as the major great power culprit in most conflicts in Africa, the Middle East, and Latin America and there has been a clear convergence in policies. Of the two major obstacles in Asia--Afghanistan and Kampuchea--progress has been made on both. China has been impressed by the withdrawal of Soviet troops from Afghanistan. Soviet support for the Vietnamese occupation of Kampuchea had been the last major outstanding issue, but by 1988, and especially Foreign Minister Shevardnadze's visit to Beijing, China accepted that Moscow had done enough in pressing the Vietnamese to leave Kampuchea. While the Soviet Union and China are unable to enforce a settlement in Indochina, they certainly have gone a 
long way to removing the issue from the Moscow-Beijing agenda ${ }^{24}$.

While some observers still dismiss such far-reaching detente as "change on the margins", this skepticism is becoming increasingly difficult to sustain. Nearly all change in international relations is on the margins (witness the 3 percent cuts in nuclear arsenals in the much-heralded INF agreement). Sino-Soviet relations will be formally normalized by the DengGorbachev summit in mid-May $1989^{25}$. Thus it is necessary to assess the main features of the new Sino-Soviet detente and its effect on the outside world.

\section{$1^{\circ}$ The Importance of Reform Communism}

The ideology that governs the Soviet Union, China, and 13 other Communist states, is undergoing its most extensive reexamination since the Chinese revolution in 1949. Not since the founding of the regimes have such fundamental questions been asked about how to adapt Communist systems to the modern world--and it is more than coincidence that both Communist superpowers are undertaking such a revision at the same time.

Important differences do exist between Chinese and Soviet Communism, but the two ideologies are now facing more similar challenges and adopting more similar solutions than at any time since the "honeymoon" in Sino-Soviet relations during the late 1950s. In fact, it is impossible to offer an adequate explanation for the cause and course of current Sino-Soviet detente without understanding the extent to which both China and the Soviet Union have served as "mirrors of socialism" for each other ${ }^{26}$. China and the Soviet Union have much to learn from each other, if only because essential features of their political systems remain similar ${ }^{27}$. Both are command economies ruled by a Communist Party. Both are large, 
continental, Communist states and therefore face different problems and opportunities than some European states. As long as reformers remain in power in both the Soviet Union and China, the similarities in their reform experiences will help ensure that both states continue to pay close attention to each other's domestic ideology. As China focuses on the initial stage of socialism and the Soviet Union elaborates its ideas of developing socialism, clearly much parallel, if not similar, ideological rethinking is taking place ${ }^{28}$. The restoration of formal ties among the media, publishers, youth leagues, and other social organizations have far-reaching implications for these one-Party states. Despite Chinese denials to Westerners that these contacts are anything but routine, there is a level of official connection peculiar to states ruled by Communist Parties. Official Chinese visitors to Moscow for the 70th anniversary of the Russian Revolution agreed with their hosts that this was "your [China's] festival too"29.

However, both the Chinese and the Soviets emphasize that the future will not include a return to the close alliance of the 1950s. Just as superpower detente in the 1980s is different from the spirit of Camp David in the late 1950s, so too does the modern Sino-Soviet friendship differ. The restoration of Partyto-Party ties signifies fully normalized relations, for between Communist states, relations at the Party level are more important than State-to-State contacts. During wars between Communist countries (China-USSR, China-Vietnam, Kampuchea-Vietnam), State ties were maintained, but Party ties were not.

The implications of the impending restoration of inter-Party ties will not be obvious to the layperson. Unlike economic agreements or even tacit arms control, it is difficult to see tangible results. But greater consultation between Party officials will help create the bonds that come from similar 
experiences in reforming Communism. Gorbachev has already learned lessons (joint ventures, special economic zones, even agricultural reform) from China and such exchanges of experience are likely to continue ${ }^{30}$. Gorbachev has demonstrated a remarkable absence of hubris in discussing reform with China, so much so that China has now accepted that Gorbachev does not seek to impose a common law on all Communists. For example, China was impressed by Gorbachev's visit to Yugoslavia in March 1988 and the apparently moderated line about the independence of Communist movements ${ }^{31}$.

The Soviet Union has openly admitted that its faulty leadership under Stalin, Brezhnev, and Khrushchev was responsible for serious errors in foreign policy that led to the split with China and border clashes ${ }^{32}$. If Chinese resentment at playing "younger brother" was at the heart of the original split, Moscow's new realism seems to have greatly impressed the Chinese. As both Parties appreciate the problems of learning from the West while avoiding the noxious influences of bourgeois liberalism, they may even begin to appreciate the greater need to distance socialist states somewhat from the market-capitalism that lies at the heart of the Pacific Century.

Certainly the distinctive pattern of trade that has developed between the Soviet Union and China owes a great deal to ideology mixed with reform. Close cooperation between planning authorities in trade arrangements suits the essentially centrally planned structure of both economies. While liberalization and decentralization are taking place in both states, the leading role of the Party and its planning authorities have not disappeared. While there are sound economic reasons for bilateral trade, the advantages that derive from trading with another centrally planned economy equally concerned about undue dependence on the capitalist system cannot be 
ignored. Both China and the Soviet Union increasingly oppose Cocom regulations especially as they hinder Japan and other developed Pacific economies from trading freely with either Communist power ${ }^{33}$.

Sino-Soviet trade and joint ventures will undoubtedly expand eventually. The trade problems experienced in 1987 have been resolved; nevertheless, as long as the reform process in both countries continues to change, the pattern of trade will remain uncertain. Chinese investment in a project in Uzbekistan, joint development of river power-generating resources, and Soviet aid to Chinese light and heavy industry are all deals that are likely to flourish. The two sides are even cooperating in the exploration of Antarctica. Decentralization in both the Soviet Union and China will aid Sino-Soviet trade as much as Western trade with China. The Soviet Union even plans to allow its regional enterprises to establish direct links with Chinese firms and department stores ${ }^{34}$. The Soviet Union and China will increase their involvement in the international socialist economy as well as in the international capitalist economy. But Sino-Soviet detente need not come at the expense of the two countries relations, with the capitalist world.

\section{$2^{\circ}$ Demilitarization and Arms Control}

Sino-Soviet detente depends to an important extent on China's perception that the Soviet Union is no longer an imminent threat and on the USSR's perception that China is unlikely to join forces with the United States and Japan in an anti-Soviet coalition. Trends in the Asian-Pacific region appear to support these premises for the foreseeable future. JapaneseAmerican and Sino-American disputes have grown in the past five years, albeit for very different reasons. Sino-American disputes over spies, technology transfer, and the description by some U.S. officials of China as a threat, indicate the obvious limits to Sino-American detente ${ }^{35}$. 
For these reasons, the bilateral detente along the SinoSoviet frontier is likely to continue. Border demarcation talks will be successful and, although some tensions will remain, both sides will have established sufficient structures for confidencebuilding that future disputes will be unlikely to become unruly. The fact that the Soviet Union is helping to fund a second Chinese rail line that will bypass the Trans-Siberian system (and surpass it in trade volume) and will provide an alternative link for European-Pacific trade, is an example of likely future cooperation $^{36}$. The more such trade links criss-cross the region, the less incentive there will be for war.

Given the geography and demography of the border regions, some instability is inevitable. If the central European frontier tells us anything, detente can incorporate both continuing military tension and basic confidence-building measures simultaneously. China and the Soviet Union are never likely to completely lower their armed guard, but detente can limit military paranoia and therefore eventually limit defense spending. Such an improved military environment leads to more cross-border contacts and greater economic integration between the two frontier regions, which in turn diminishes the likelihood of conflict.

Clearly, the Sino-Soviet military relationship is not strictly bilateral. The Soviet invasion of Afghanistan derailed an earlier attempt at Sino-Soviet detente. China has been impressed by the triumph of a small neighbor's nationalism over the might of the Soviet Red Army. But it is also concerned that the power of such nationalism, when coupled with a potent religion, can defeat the appeal of modernizing Communism. The implications for the USSR's own nationality problems are not too different from the potentially destabilizing effect on China's own fringes. China's Tibet problem is a case in point. As both Communist powers are the only two old empires still in control 
of their vassals, they tread carefully when confronting the power of nationalism.

Nationalism is also at the root of the Vietnam-Kampuchea problem. Vietnam's occupation of Kampuchea is related to ancient Vietnamese claims of influence throughout Indochina. Hence China's desire to control Vietnam also has deep historical, nationalist roots. The Soviet Union has encountered this nationalism when trying to encourage Vietnam to leave Kampuchea, and Moscow has found it difficult to build bridges to the Communist governments of Laos and Kampuchea without antagonizing its Vietnamese ally. Until recently, China's own nationalism prevented it from lifting some of its pressure on Vietnam. If Beijing were to limit its pressure on Vietnam, it is likely that natural Kampuchean nationalism, plus the Soviet desire to move independently of Vietnam, could result in a less powerful Vietnamese role in the region.

But even if the Chinese strategy of getting at Vietnam through the Soviet Union has delayed a settlement, most signs now indicate that a deal is in sight. China's decision to allow Prince Sihanouk some manoeuvering space suggests it might now be willing to give Kampuchean nationalism a chance. Under Soviet pressure, Vietnam has certainly eased its hard line, and now has the positive example of the Soviet withdrawal from Afghanistan. In May 1988, Vietnam announced that half its remaining troops in Kampuchea would be withdrawn, beginning in June, while the last contingents would be placed under Kampuchean control. The complete withdrawal was promised by $1990^{37}$. It is still too early to tell what the future of Kampuchea will be, but it is already clear that China and the Soviet Union have moderated their own positions sufficiently to allow a Sino-Soviet summit. China still notes the issues are not fully resolved, but at least it is now 
more willing to tolerate some unpleasant aspects of Soviet policy $^{38}$.

China's growing naval presence in the disputed Spratly islands off Vietnam in March 1988 put the new Soviet thinking to the test. Moscow's lukewarm support for Vietnam's position suggested that China might well be able to take advantage of the Soviet desire to protect Sino-Soviet detente to satisfy China's nationalist claims. At a time of Chinese sensitivity because of unrest in Tibet, unresolved nationalism remains a potent problem.

Thus the new agenda for Sino-Soviet relations in Indochina will focus more on competititon for influence among national Communisms than mirror the outright hostility of the 1970's. Assuming that Vietnam does withdraw from Kampuchea by 1990, the day is not far off when the Communist states of the Pacific can begin to cooperate in peace. The possibilities for a Sino-Vietnamese detente eventually developing in ways similar to Sino-Soviet detente must be taken seriously. The possibilities of greater cooperation among all the Communist states of the Pacific might offer an alternative to closer integration with the capitalist world. Certainly, control over the last remaining hot wars in the Pacific will mean that the military dimension of Sino-Soviet relations will be less important than at any time since the 1950s.

\section{$3^{\circ}$ The Great Power Triangle}

The great power triangle has been a feature of Sino-Soviet relations from the time the People's Republic of China was created in 1949. Only in the late 1980s did both Communist powers learn that a degree of cooperation and conflict with the United States was normal for both states. To benefit most, all three states must have a least a modicum of detente with each other. In an era of detente, this competition in cooperation 
encourages diplomatic shuttles between capitals as each country tries to ensure it is not missing out on subtle maneuvering.

In an era of declining superpower influence and the rising power of Japan and China, such games are even more difficult. The historical pattern suggests that as long as no side suffers prolonged setbacks, all will tolerate the spiral of detente. Thus, a superpower arms control agreement no longer results in fallouts between China and the Soviet Union or China and the United States. Similarly, Sino-American relations do not collapse as Sino-Soviet detente develops, and Sino-Soviet detente does not fade when the United States sells arms to China.

The great power relationship has become more stable, largely because China has matured. It was a potent mix of Chinese, and to some extent, Soviet paranoia that prohibited the great power triangle from adjusting itself at the margins without one party complaining loudly. The development of genuine independence in Chinese foreign policy has been appreaciated in both Moscow and Washington. Although the United States complains about China's "two Americas policy" (China's habit of taking American aid while denoucing some of its policies), the new triangle will make such policy dilemmas more natural and less destabilizing.

Yet other sources of destabilization do exist. For example, there is the issue of Japanese rearmament--the problem of the Japanese economic superpower searching for a broader foreign policy role is one of the great imponderables of future Pacific international politics. The United States has urged Japan to spend more on defence, and Japan now has the largest defence budget after the superpowers. The purposes of this new power 
deeply concern China, the Soviet Union and various other Pacific states ${ }^{39}$.

The more China and the Soviet Union denounce Japanese rearmament, the less reason they will have to be in dispute. While the renewed Sino-Soviet detente does not signal a return to the 1950s balance of power, when the Sino-Soviet alliance was explicitly forged against Japan, it is instructive that SinoSoviet detente can still be enhanced by a growing sense of common threat. It is difficult to imagine anyway that the Japanse military buildup can occur without upsetting both China and the USSR. Simply put, the crucial North Pacific balance is necessarily a complex mix of two superpowers and two mismatched great powers, China and Japan. Concerns about Japan and the United States have been emphasized in Soviet Pacific naval strategy for five years, as has China's move to a blue-water navy and its diminishing concern about the threat from Soviet ground forces. This quadrilateral balance of power may well replace triangular thinking and offer further prospects for a less obsessive attitude between the Soviets and Chinese.

\section{$4^{\circ}$ New International Relations}

New trends in the broader international system are helping to reshape Sino-Soviet relations. One vital tendency is the reduction in military conflict in East Asia and a general retreat of the superpowers from foreign military engagements. A constant feature of Soviet superpower status was the belief that the country was better able to compete militarily than economically ${ }^{40}$. This incomplete superpower derived much influence from its ability to intervene around the globe and support allies at war. China, by contrast, had no such reach and as in the Angolan civil war, had to retreat from confrontation. China's sense of inferiority vis-à-vis the Soviet Union had much to do with its inability to compete militarily. 
With reduced opportunities for intervention, especially in East Asia, China felt more comfortable about detente with the USSR. At the same time, the Soviet Union and the United States were at least tacitly cooperating to keep the conflicts under control and avoid direct intervention, as seen most vividly in the Gulf war. For its part, China was testing a new, very different policy toward distant conflicts. Its massive provision of arms to both sides of the Iran-Iraq conflict showed that China could begin to compete on superpower terms; in fact,, Beijing perceived benefits (primarily economic) from conflict in the developing world. The gap between Chinese and Soviet power projection capability was being reduced, but at a time when the superpowers perceived a declining utility in such long-range power.

When these trends are coupled with the new pragmatism in Chinese foreign policy, for example in dealing with South Korea, Israel and Saudi Arabia ${ }^{41}$, it is clear that the Soviet Union and China have fewer disputes around the globe than at any time since the 1950s. If they continue to agree, in most cases, that the United States is the main problem in Third World conflict, then even a more assertive Chinese foreign policy will not upset Sino-Soviet relations. Allowing China to arm Iran enables the Soviet Union to profess good intentions in its dealings with the United States and foster superpower detente. The current situation is in marked contrast to the problems such entangling conflicts in the developing world caused for the last version of superpower detente in the 1970s.

In general, the decline of direct intervention in conflicts in developing states is likely to mean less friction in Sino-Soviet relations. It is also likely to drive both Communist powers into a more economic-based foreign policy as both concentrate on their domestic modernization. Moreover, like other great 
powers, China and the USSR have also come to accept that its is necessary to rethink old images of the Third World.

This rethinking is based on the rise of the NICs, the majority in East $\mathrm{Asia}^{42}$. Their development suggests that the route to modernization is not through isolation from international capital, as Tanzania attempted. Rather the route to greater strength and independence is, paradoxically, through greater interdependence in the international market. Even continental Communist powers have come to recognize that they can benefit from the international capitalist economy without losing control of their destiny.

Of course, the need to modernize the decrepit ecoomies of the leading Communist states had its own motivations deep within the centrally planned system. As the success of China has shown, reform that includes an opening up to the international economy can be highly successful. The Soviet Union has paid attention to these lessons. Thus Moscow and Beijing are cooperating in reform Communism, and they are exploring new contacts with a wide range of states in the developing world. The East Asian NICs are particularly attractive to both states and, given their location, the parallel advances from both Communist powers helps ensure stability in the region.

The new Sino-Soviet detente has facilitated Chinese and Soviet trade with South Korea, Taiwan, ASEAN and even Hong Kong ${ }^{43}$. Sino-Soviet detente appears to be leading to more varied patterns of international economic relations in the Pacific. Although the Soviet Union is aware that, to some extent, the two Communist powers are economic competitors, Moscow wants to use more commodity trade than China, which is more interested in industrial coproduction ${ }^{44}$. 
Once again, reform Communism, this time coupled with new trends in the international economy, is bringing Moscow and Beijing closer. They may draw closer still, since both appear to have deep reservations about unrestricted involvement in the international capitalist economy. A new challenge, if not a new option for the two countries, will be the creation of a more integrated and successful international socialist economy. With the new ideas of reform Communism, a looser and more efficient basis for cooperation might be found ${ }^{45}$. If the burgeoning Sino-Soviet and Sino-Mongolian trade are proof, there is much room for improvement and some scope for an international socialist division of labor.

\section{$5^{\circ}$ The New Sino-Soviet Agenda}

The new Sino-Soviet detente is driven by the twin engines of the need for domestic reform and new trends in the international environment, yet the craft is still buffeted by unexpected winds. There will continue to be turbulent times in Sino-Soviet relations, but any mature detente between great powers will incorporate both competition and cooperation.

Clearly, Sino-Soviet relations have changed dramatically from even a decade ago. Trends for the future suggest even greater cooperation to be derived from the parallel reform process, although profound doubts must remain about how successful the reforms will be in the long run. Economic cooperation is likely to expand, resulting in new and increasingly complex foreign trade ventures and accelerating the decentralization process in both countries.

The confrontational military dimension of the relationship is clearly declining and it seems clear that there will be fewer disputed bilateral and multilateral military issues. The Soviet Union will remain the main potential threat to Chinese security, but this threat will be reduced, while other distracting threats 
may emanate from Japan or Taiwan. Certainly, there will be less room for the United States to exploit either Soviet or Chinese fears within the great power triangle. The pattern of interdependence in Asia, the Pacific and the international balance of power is evident.

The main states to gain from this detente, in addition to China and the USSR, will be most of their East Asian neighbors. Reduced tensions will please most states, although perhaps not initially the East Asian Communists, who will be pressured to reform. Other Asian states, such as India or Pakistan, might also suffer as their ability to play one Communist power against the other is reduced.

Japan, the United States, and indeed the West Europeans have a more complex judgment to make. They will undoubtedly benefit from reduced tensions and the ability of East Asians to move toward economic prosperity relatively free of war scares. Sino-Soviet detente is in the interest of the major Western powers in the short-, and perhaps even midterm future, but this new age of Sino-Soviet detente may also pose greater challenges for the West. If reform Communism is successful and another viable option for development and modernization emerges, the pleasure that the West derives from comparing Communist basket cases to the East Asian NICs may then fade. More disturbing still, prolonged Communist detente might help shift the vital northeast Asian balance of power. Japan, increasingly dissatisfied with its Mutual Assured Destruction (MAD) economic relationship with the United States (the ability of both to do serious harm to the other's economy), might seek the greater independence that is likely to come from building bridges to a more amenable Communist world next door in Asia. Three-way trade relations might offer an interesting mix of markets and resources and help lessen dependence on the United States. Certainly a China and a Soviet Union more 
committed to international economic relations might seem less fearful to Japan.

\section{The Potential of Japan}

The Soviet Union first consolidated its detente with China, and Japan appears to be next on the Soviet agenda in the Pacific. However, the Soviet Union knows that it probably cannot easily achieve the same kind of rapid results with Japan as it has with China. Traditionally, Russia has always had problems in simultaneously improving relations with both China and Japan and since 1945, the task has become even more difficult. But now that Sino-Soviet relations are normalized, detente with Japan cannot be far behind.

The Soviet need to choose between the two great East Asian powers was based on a number of factors, including ideology and suspicion of a quadrilateral balance of power in northeast Asia. If only because of its vast border with China, Sino-Soviet relations were always likely to be more important for the Soviet Union. Moreover, a positive response to Soviet overtures seemed more probable from China than from Japan. Thus, when Mikhail Gorbachev decided to remake Soviet policy in the Pacific, it was only natural that China would be the first target. It was equally natural that Japan would be piqued.

$1^{\circ}$ Japanese Independence

Japan, like Britain, is notable for its close relations with the United States, and its ability to distance itself from continental security concerns if it so desires. In the case of Great Britain, Mrs. Thatcher's closeness to the United States makes Britain an attractive partner for the Soviet Union to use in making overtures to Washington. But so far, Japan has not benefited from a similar Soviet initiative. The reasons are related to the 
Soviet Union's China initiative and to Japanese coolness to Soviet overtures.

Unlike West European countries, Japan has few local allies to give breadth to its foreign policy. In an era of growing trade friction with the United States and the hollowing out of sectors of the Japanese economy, Tokyo has barely moved past the slogans of internationalism in search of a more genuinely independent foreign policy. As an economic superpower and a international political dwarf, Japan poses awkward problems for the Soviet Union.

If the Soviet Union is content to leave Japan as a U.S. ally and simply concentrate on developing the great power triangle in the Pacific, then Soviet-Japanese relations will stagnate. It would certainly be more challenging and perhaps more productive, for the Soviet Union to anticipate the possibility of encouraging Japan to adopt a more genuinely independent position.

Based on history, the risks of a more independent Japan are evident throughout the Pacific. In the 1930s, however, China had no real power to stand up to Japan, and it was only the Manchurian campaign in 1945 that brought Soviet military power to the Pacific in strength. A more independent Japan in the twenty-first century would be far more constrained by the Communist powers.

To a large extent, the Soviet Union can count on Japanese confidence and arrogance to encourage Tokyo to develop greater independence, but if the result is to be favorable to Soviet interests, the Soviet Union must also encourage the Japanese to include the Soviets in any new plans. While possible, this will require even more reform and initiative from Mikhail Gorbachev. 


\section{$2^{\circ}$ Territory and Security}

Japanese discussions about the return of the Northern Territories are not very different from pre-Helsinki West European demands for territorial adjustment. Few had any real expectation that territory would change hands, but the West Germans in particular had good domestic and alliance reasons for keeping up the revanchist line. Helsinki essentially ratified the broad principle hammered out in the series of treaties resulting from Brandt's Ostpolitik. Whether Japan is on the verge of emulating Brandt remains to be seen.

The differences between European and Pacific security are obvious, as are the differences between Japan and Germany. For instance, Japan can develop relations with Communist China without going through Moscow and there are no ethnicJapanese "held hostage" by a state allied to the Soviet Union. But at least one essential commonality is important--Japan, like Germany, increasingly recognizes that genuine independence requires building bridges to Moscow. The dream of a strong Sino-Japanese relationship is now fading in Tokyo, especially as China begins to strike deals with the NICs and undercuts the terms of Sino-Japanese economic cooperation. The more obvious Japanese-American difficulties also raise basic questions about Japan's role into the twenty-first century.

Throughout the years, the territorial issue has become more of a political symbol; there is increasing evidence that a symbolic agreement on the northern territories will shift the domestic Japanese debate sufficiently to remove the territorial issue. Similarly, the question of principle rather than territory is also evident in Sino-Soviet detente as they resolve their border dispute. Little land, and certainly nothing of importance will change hands, but China is satisfied that the principle of a Soviet concession has been made. It is partly a matter of pride, but more likely a matter of being treated as an equal, that is so 
important to weaker powers dealing with the Soviet superpower.

If a symbolic arrangement can be made, resulting changes could include regular meetings of Soviet and Japanese leaders, official Japanese support for exploration of economic contacts, and admission of the Soviet Union as a PECC member and participant in Pacific-wide discussions. Such an arrangement will not eliminate the Soviet Union as Japan's major security concern, nor will it make the Japanese-American security framework obsolete. Japan, like China, can only deal with the Soviet Union from a "position of strength". But a more confident Japan, like France, may well slip out from under the U.S. security umbrella, content to know the Americans are never far away in case of crisis.

\section{$3^{\circ}$ Economic Potential}

Security concerns are usually placed first in discussions of Soviet-Japanese relations, but that should not disguise the fact that economic cooperation will cement any more positive future relationship. Among the factors that could contribute to improved bilateral relations are the complementary resources and level of economic development between the Soviet Far East and Japan; Soviet appreciation of Japanese economic success; Soviet desire to demonstrate greater openness; the decentralization of the Soviet economy and priority being given to the Far East; and the advent of a new generation of more sophisticated Japanologists.

In terms of joint ventures, the Soviet Union is evidently more interested in Japanese contributions of technology (especially electronics) than in investment. Soviet officials speak of the need for new forms of cooperation such as free-trade zones and coproduction agreements as part of the development plans through the year 2000. Moscow sees the Japanese being 
squeezed between American protectionism and Chinese diversification. It expects Japan to diversify, moving more into Europe and East Asia and hopes for Japanese ventures in the Soviet Union. As the industrial spin-offs from the hollowing out of the Japanese economy emerge, the Soviet Union sees itself well placed to exploit some of the benefits ${ }^{46}$.

Soviet plans for special economic zones and joint ventures differ from the Chinese experience in that the Soviet Union will concentrate on raw material or processed raw material exports. By emphasizing at least basic processing of these resources, the Soviet Union hopes to be the provider of basic building blocks of economic success to a booming economic region ${ }^{4}$. Such a trade strategy depends not only on the success of Soviet reforms at home but also on the continuing need for Soviet raw materials. The lessons of the Gulf war, possible dangers in the South China Sea, and American unwillingness to sell Alaskan oil to Japan, should provide enough evidence to Japanese planners that diversification of raw materials must sensibly include purchases from the Soviet Union.

Perhaps one of the best ways to tie the Soviet Union into the international economic culture of stability in the Pacific will be through multilateral economic deals. When Japanese firms arrange for Chinese shipyards to repair Soviet ships, whose catch is then marketed by Japan, it is clear that interesting deals are possible. As the decentralization of the Soviet economy takes shape, the possibilities for complex multilateral joint ventures multiply. In addition, as the Soviet Union encourages Vietnam and North Korea to open up to Japanese investment, Tokyo will know that stable relations with the Soviet Union are essential to gaining access to all markets in the Pacific.

In return, the Soviet Union will expect Japanese investment in specific projects and special economic zones and it will also 
expect Japan to continue to be willing to sell sensitive high technology. The globalization of technology trade will help ensure that the Soviet Union has access to the most up-to-date Western technology and a vital card to play when negotiating with other Western companies.

Participation in PECC and a more general normalization of the Soviet role in the Pacific is also likely to follow as part of Soviet-Japanese detente. The Soviet Union has created a national committee to work for membership in the PECC process and Japan seems to be softening its line against Soviet participation $^{48}$. Soviet representatives attended the May 1988 meeting in Osaka, largely because of the change in the Japanese line. Japanese approval is perhaps worth more than approval from the United States, at least in the Pacific.

Soviet officials now admit the errors of previous policies on Pacific cooperation and have begun to contemplate several new ideas for attracting foreign investment. How much autonomy will be granted to the Soviet Far East remains the basic Soviet dilemma ${ }^{49}$.

\section{Towards a Pacific Socialist Community}

Since the triumph of Communism in China in 1949, there have been few real gains for socialism. Considering the scale of the virtually uncontrolled process of decolonization, it is remarkable how few states adopted the state socialism of a one-Marxist-party state. Four of the nine new Communist regimes are in Asia and three of these four are in East AsiaPacific. By the late 1970s, there were nearly as many Communist regimes in Asia as in Europe ${ }^{50}$.

The triumph of Communism in Vietnam, Laos and Kampuchea proved to be a mixed blessing for the Soviet Union. 
The regimes in Laos and Kampuchea were among the poorest in the world and like most allied developing states, have been a burden on the Soviet Union. Kampuchea was to prove even more difficult, for under the Pol Pot regime, it waged war on Vietnam, drew Soviet support for Hanoi's imposition of a puppet regime and created a major obstacle to improved Soviet relations with China and ASEAN.

The spread of Communism was hardly an advertisement for the benefits of alliance with the Soviet Union and a Soviet leadership that was relatively uninterested in the Pacific was unlikely to offer new thoughts on relations with its Pacific socialist community. New thoughts were also unlikely because of the vast differences and distances between the Pacific Communist states. Mongolia, the oldest ally, was almost totally dependent on the Soviet Union and deeply suspicious of any Sino-Soviet detente ${ }^{51}$. North Korea had long ago learned how to exploit Sino-Soviet rivalry and it grew concerned as detente allowed less room for maneuver. Vietnam had also played off the two Communist powers, but since the late 1970s had become heavily reliant on Soviet aid. Hanoi's fear of a Soviet sell out to ease Sino-Soviet detente have proved correct. Laos and Kampuchea were clearly within the Vietnamese orbit and offered little advantage and a great deal of headache to a reform-minded Soviet leadership.

\section{$1^{\circ}$ Domestic Reform}

The Soviet calculation of costs and benefits for the Pacific Communist regimes is less favorable than for the European regimes. The Pacific states are clearly more of an economic burden and will probably remain a frustration for the foreseeable future. The benefits are found in the more intangible dimension of military strategy and ideological rivalry. The obvious conclusion, finally acted on by Mikhail Gorbachev, was to risk some of the intangibles to reduce 
economic costs. The method, as applied domestically in the Soviet Union, was reform.

Vietnam by far the largest of the burdens, was first to feel the brisk winds of restructuring. With estimates of up to $\$ 5$ million per day being sunk into Vietnam, Gorbachev decided to obtain more reform for his rubles. In late 1986, the Vietnamese were pressured into changing their leadership and experimenting with economic and political reforms. The process obviously lags behind that of China and the Soviet Union, but it is more advanced than anywhere else in Communist $\mathrm{Asia}^{52}$. The Soviet Central Committee has held several extraordinary meetings to develop new aid packages to Vietnam that were tied to reforms and promises from Hanoi not to waste aid as they had in the past ${ }^{53}$. At its most basic level, this carrot and stick strategy is intended to reduce the Vietnamese burden on the USSR.

More positively, the strategy is intended to transform Vietnam from a liability to a living example of the benefits of socialism. The scope for Soviet-Vietnamese economic cooperation is only now being properly explored. Soviet commentaries speak of the need to break out of old molds of thinking. The use of Vietnamese contract labor in the Soviet Far East (and in the German Democratic Republic) is a case in point and is intended to help solve severe Soviet labor shortages in its Pacific region ${ }^{54}$. Other new ideas include Soviet aid for the Vietnamese fishing industry and joint ventures that will involve produce sales to third countries ${ }^{55}$.

Vietnam has not yet made the transition from a war economy to a peaceful experiment in peasant socialism. In theory, the potential for successful reform in Vietnam is greater than anywhere in the region. With the positive example of Chinese agricultural reforms, now approved by Soviet 
commentaries, Vietnam could achieve the kind of rapid and easy growth that China demonstrated in the past decade. The easing of the burden would be appreciated in Moscow and elsewhere within the Council of Mutual Economic Assistance (Comecon) where the commitment to aid Vietnamese reconstruction has been resented.

Vietnam can, in fact, detract from the Chinese reform, by showing that even a state closely allied to the Soviet Union can achieve the kind of success so far seen only in China. To the extent that the Soviet Union is still concerned about alternative models of socialism (although Gorbachev seems more tolerant of different roads), diluting the importance of Chinese success will still be necessary.

The risks of Vietnamese success are, as in the case of China, that Vietnam will build bridges elsewhere in the Pacific and therefore diminish Soviet influence. As the third most populous Communist state, Vietnam has the potential for a far more independent policy. Japan seems the most likely source of investment in Vietnam and some ASEAN states are also beginning to think of Vietnam as a partner. A confident Soviet Union will see in this diversification of Vietnamese policy the possibility of an enhanced Soviet relationship with Japan and ASEAN; however, an insecure Soviet Union will fear for its control and see another example of an ungrateful Communist ally (like China) slipping its moorings once the seas were calmed.

The two other Indochinese Communist states, Laos and Kampuchea, are much smaller burdens and far less important to the USSR. So far, Vietnam has kept Moscow at arms length in these states for fear that the Soviet Union will develop its own channels to these governments ${ }^{56}$. Yet if Vietnam withdraws its direct control over Laos and Kampuchea after 
1990, the scope for Soviet development of direct relations will increase.

The main benefit for the Soviet Union will be to provide more checks and balances should Vietnam move to a more independent position. By capitalizing on local nationalism and offering to provide support, say to Kampuchea if Vietnam becomes difficults, the Soviet Union could help keep an uneasy band of allies together. But apart from the arcane game of Communist Party factional politics, it is difficult to see what major benefits the Soviet Union hopes to obtain from Laos and Kampuchea.

Far more important to the Soviet Union are the northwest Pacific Communist states of Korea and Mongolia. Like the other allies in the region, these two provide different challenges and require the application of different Soviet policies. In terms of greater cooperation among socialist states in the Pacific, however, this very diversity can be advantageous for the Soviets. The North Korean economy, now at a virtual standstill, was once a model of Soviet-aided socialism in the developing world ${ }^{57}$. Certainly in comparison to South Korea, the model has lost its shine. The Soviets state clearly that North Korea, like Vietnam, has not made the most of Soviet assistance and that reform in the North Korean economy is long overdue ${ }^{58}$. As the most industrialized of the Pacific Communist states, North Korea could be turned into a more efficient producer of industrial goods in exchange for light industrial products and food from Indochina ${ }^{59}$. Such efforts, combined with Soviet raw materials and Chinese products, could produce a model of cooperation in the Pacific that is not based on market economies $^{60}$.

The requirements for such a socialist community depend heavily on the success of Soviet reform efforts, as well as 
efforts by the Pacific Communist regimes. North Korea has been slow in moving toward reform, despite dual pressure from Moscow and Beijing. The anticipation of Kim Il Sung's succession may account for part of this delay and it is likely that both the USSR and China are moving behind the scenes to ensure some reform once the succession takes place. Despite cautious skepticism by outside observers, recent successions in the other Pacific Communist states have shown that reform has followed a change of leadership.

The Soviet Union has already managed to change the leadership and begin the process of reform in Mongolia. The Mongolian state will always remain artificial, sandwiched as it is between China and the Soviet Union. While MongolianChinese tension has lessened because of the Sino-Soviet detente, Mongolia's fear of China will mean its reliance on the Soviet Union and is unlikely to change. Mongolia will remain a conservative barometer of reform and cooperation in the Communist Pacific. Recent discussions of rail links, increased cross-border trade and multilateral cooperation with China, the Soviet Union and even North Korea, suggest that Mongolia is part of the new spirit of cooperation. Cooperation on rail links among the four northeast Asian Communist states is already well underway and there are indications that other multilateral arrangements are being explored ${ }^{61}$. If the positive mood prevails, then Mongolia's raw materials will travel to other parts of the Pacific aside from the Soviet Union. But unlike Vietnam, Mongolia has no real option of independence; therefore, the USSR is less concerned about pressuring the Mongolians.

The USSR will tolerate a degree of diversity among the Pacific Communist states and if Eastern Europe is any model, that degree is increasing. An optimistic and ambitious Soviet leadership can use that diversity to shape a more efficient 
socialist community in the Pacific. As with most other elements of change in the region, success depends on reforms at home and their successful transfer to the different conditions of other socialist states.

As remote as the idea of closer cooperation may sound, it is not any more remote than the talk of economic cooperation among market economies of the Pacific. The Soviet Union remains ambiguous about whether it seriously wishes to develop the Communist Pacific community idea or whether it is just trying to strengthen its application for full membership in a broader Pacific-wide scheme. While the Soviet Union cannot ensure that its allies participate in a broader scheme, it can do more than any other state to ensure that Pacific cooperation proceeds in a peaceful atmosphere and with constructive contributions from its Communist members. For the time being, the Soviet Union appears to be keeping its options open.

\section{$2^{\circ}$ Reducing Military Tensions}

The two major areas of military tension in the Pacific involve Soviet allies. In Korea, the conflict has been under control for some time but could still erupt. In Indochina, tension is declining, but it continues to be a major obstacle to the vital normalization of Sino-Soviet relations. In both cases, the Soviet Union has become a major supporter of detente.

The Korean issue is perhaps the most illuminating example of the importance of Sino-Soviet detente and the way in which it affords the USSR possibilities in the Pacific. The Soviet Union has long supported detente on the Korean peninsula, but as long as China offered Pyongyang a radical alternative, there was little hope of stabilizing the conflict. China's shift in the 1980 s to pragmatic relations with South Korea enabled the Soviets to explore their own contacts with the South. China's trade with South Korea is worth up to ten times the Soviet 
total, but the Soviet Union is perhaps moving faster in establishing formal ties. Certainly its East European allies are at an advanced stage of establishing official trade relations ${ }^{62}$.

If the Soviet Union is successful, North Korean reaction to what it considers a sell out of its interests will be that Pyongyang will read the writing on the wall and improve its relations with South Korea. As the two Korean societies grow farther apart, a solution similar to Germany's becomes more likely. Mutual recognition, albeit possibly under the ruse of "one country, two systems", could allow the two Koreas to mature. Their neighbours might then move toward closer cooperation. Because the Cold War came to the Pacific later than to Europe, detente will also take longer to arrive.

Another example of Sino-Soviet detente changing the pattern of Pacific tension is in Indochina. The Soviet Union realized that China needed to see some reduction in the Vietnamese threat before it could normalize relations with the Soviet Union. While China offered some concessions (such as accepting that the Soviet presence in Vietnamese bases was not an obstacle to Sino-Soviet detente), the Soviet Union has offered some compromises of its own. Moscow now discusses the question of Vietnamese occupation of Kampuchea in talks with China and by 1987 China had even recognized that the Soviet were pressuring Vietnam to withdraw from Kampuchea. In July 1987 Gorbachev made clear that he was sure that Vietnam would keep its promise to leave Kampuchea by 1990.

The Soviet strategy aims to manage this withdrawal so that Kampuchea does not slip back into a Chinese sphere of influence and Vietnam does not force the Soviet Union to abandon its bases. This is a high-risk strategy, but the stakes involve improving relations with China and ASEAN and removing the stigma of responsibility for the Pacific's only 
major continuing conflicts. Prince Sihanouk's overtures in 1988 to the Vietnamese-backed Kampucheans were strongly supported by the USSR as a possible compromise ${ }^{63}$. Much like the search for a face-saving formula in Afghanistan, the Soviet Union has clearly been looking for ways to reduce its draining commitments to the developing world; however, much can still go wrong.

Vietnam will hope to leave Kampuchea with a friendly regime in place and to maintain control through many of the same mechanisms of Party authority that the USSR exercises in Eastern Europe. If successful, Vietnam will have less need for Soviet support; the price for access to Vietnamese bases will therefore rise. The right to use the bases might even be eliminated if Vietnam opts for closer cooperation with nonCommunist Pacific states. Of course, the flaw in the scenario for Vietnamese independence is the threat from China.

As the March 1988 clashes over the Spratly islands indicated, the Sino-Vietnamese dispute is not limited to Kampuchea. As long as China feels that Vietnam does not recognize China's leading role in East Asia and believes Vietnam to be impeding Chinese irredentism, then Beijing will continue its pressure. As worrying as this might be for the USSR, the continuation of tension does have its advantages.

Vietnam will be less likely to request a Soviet withdrawal if it still feels a need for Soviet aid against China. The Soviet dilemma, as it knows only too well from its relationship with China and India, is how to convince China and Vietnam that it is evenhanded and sympathetic to both their positions. The first sign that the Soviet Union appreciated the complexity of the game was seen in its carefully constructed policy in the March 1988 clash in the Spratlys. The Soviet Union avoided supporting Vietnamese claims but not so obviously as to drive Vietnam to 
retaliate against Soviet interests ${ }^{64}$. Only the Soviet Union can provide Vietnam with military support sufficient to deter China and Moscow clearly declined to do so in March. If China persists in pressing its territorial claims, then the Soviet Union is likely to offer Vietnam only verbal support while allowing China to settle old scores. Of course, the Soviet Union will hope that China will not force Moscow's hand.

Thus it seems unlikely that a genuine socialist Pacific community can be created. Moscow's ability to impose order in the Pacific is more limited than in Eastern Europe. In the Pacific, Communist states have gone to war against each other and will probably have tense relations in the future. Under these circumstances, the Soviet Union will have to choose among its fellow socialist states. China is the most important, but the most independent. Vietnam ranks next in importance but is the most antagonistic to China. While the Soviet Union will explore the possibilities of shaping a more coherent socialist community, it will probably settle for separate multilateral relations, often involving non-Communist states. The northwest Pacific holds the best prospects for such cooperation.

\section{The Capitalist Pacific}

One of the main, though unstated, motives for Soviet pressure on its socialist allies to reform is the significantly better economic performance of their neighbours in the NICs and in part of ASEAN. The Soviet Union has realized that something important is happening in the Pacific's developing world, which holds prospects for improving the Soviet position in the region. The capitalist Pacific (apart from Japan and the United States) remains a diverse grouping and requires different Soviet strategies. For the most part, the Soviet Union is most interested in states closest to East Asia and less interested in the truly Pacific states.

$1^{\circ}$ NICs and Proto-NICs 
$1^{\circ} \mathrm{NICs}$ and Proto-NICs

The Soviet Union has never had a satisfactory relationship with many non-Communist developing states. Unlike the developed West, the Soviet Union trades little with these states and prefers to concentrate on a few specific partners such as India or Cuba. In the age of new international economic orders and the heyday of the nonaligned movement, the Soviet Union felt it understood the dependency between neo-colonialists and their former pupils in the South. But new thinking in the Soviet Union and new realities in the developing world have finally contributed to a more sophisticated Soviet view of the South.

The emergence of the successful NICs in East Asia (HongKong, Singapore, South Korea, Taiwan) raises a variety of problems for the Soviet Union. All four are closely linked to the Western trading world and only Singapore has official ties with the Soviet Union. Yet all four are prime examples of the benefits of "thinking Pacific" and the possibilities for economic cooperation in the region. All four have sharply anti-socialist ideologies, all except Hong Kong have succeeded through a large degree of state direction and none has a democratic system as recognized by the developed Western states. The NICs and perhaps the proto-NICs of Malaysia and Thailand, are evidence that what is happening in East Asia requires new categories of thinking. As a pragmatic China has shown, it is possible to trade with all of these states, despite the occasional absence of diplomatic relations.

While Soviet policy remains officially critical of all NICs, contacts have been opened with South Korea, Taiwan and Hong Kong to explore trade possibilities ${ }^{65}$. The political benefits the Soviet Union might derive from such ties are secondary and indeed the USSR risks complicating relations with North Korea 
as it makes overtures to South Korea. The economic benefits of the Soviet relationship to the NICs are more evident.

As Soviet policy toward ASEAN demonstrates the fundamental Soviet problem of finding goods to export to the developing Pacific states still remains. Raw materials continue to be the Soviet Union's staple export. While imports from Singapore and Malaysia have roughly approximated the level of Soviet trade, say with Turkey, the Soviet Union has found it virtually impossible to export. Possible new Soviet initiatives include machinery exports (for textiles, timber industry, fisheries) and gold sales to Asia through Singapore ${ }^{66}$. The development of economic relations depends on the conditions for investment by the NICs and for joint ventures in the Soviet Union and on finding Soviet products to export. Once again, it appears that raw materials or heavy industrial products, such as steel, will have to constitute the largest portion of Soviet exports. Yet as Canada and Australia already know, dependence on raw material exports is not desirable in an age when modern economies are moving into high technology and services. It is precisely because the Soviet Union recognizes the need to think in new categories about the Pacific that it has begun to consider structural compatibility with some of the NICs. South Korea is clearly the new favorite--with an economy and level of technology well suited to Soviet needs. Deals are being negotiated that would bring South Korean capital, technology and even labor to the Soviet Far East to establish a local manufacturing base.

At the same time, the Soviet Union could obtain the far more intangible benefits of more normal political and military relations with the NICs and especially ASEAN. The stream of high-level delegations to and from Moscow beginning in 1987 is evidence of Soviet interest in and potential for playing a more positive role in the Pacific ${ }^{67}$. There has also been some 
discussion of a new Soviet drive in heavy machinery exports to ASEAN, even to Malaysia, including military equipment ${ }^{68}$. Uncertainty about what tangible benefits can be derived from closer contacts with the Soviet Union remains a common refrain. Settling the conflicts in Korea and Indochina is the primary interest and in both cases there is confidence that the Soviet Union is beginning to deliver on promises of a more peaceful attitude.

Assuming an improved political atmosphere and at least a modest upturn in economic relations, the Soviet Union could anticipate its more genuine acceptance as a Pacific power. Debates, such as those that divide ASEAN whenever Indonesia argues for better relations with Moscow, would then become less frequent. At some point, there appears to be a basic conflict between the possible cohesion of a putative Communist community in the Pacific and the Soviet desire for improved relations with the NICs and ASEAN. While the USSR desires a more peaceful atmosphere focused on the pursuit of domestic reform, there are few sound economic reasons for the Soviet Union to buy industrial goods from North Korea when it could buy better and less expensive items from some of the NICs.

\section{$2^{\circ}$ Across the Pacific}

The Soviet Union is more likely to think in terms of East Asia than the Pacific if only for reasons of geography. Trade with North America is easier across the Atlantic and trade with Latin America (especially Pacific Latin America), is negligible. Thus the Wider Pacific waters are only important as waterways to Australia and New Zealand where there are economic interests for the Soviet Union. Soviet imports from these South Pacific states are equal to those from Britain. But as with the ASEAN states, the problem for Moscow is its pathetic level of exports. Unlike some of the NICs or ASEAN, Australia and New Zealand have even less need for Soviet raw materials. 
As close allies of the United States, Australia and New Zealand were also difficult to exploit politically. Unlike U.S. West European allies, there have been few carrots that Moscow can proffer and very few sticks that can be waved with any effect. The problems in ANZUS in the 1980s owe nothing to Soviet initiatives and all to the politics of New Zealand and its bilateral relations with the United States.

The desire to make the South Pacific relatively free from the dangers of the nuclear age has offered the Soviet Union some room for exploitation. Although New Zealand has steadfastly refused to compensate for poor relations with Washington by approaches to Moscow, other South Pacific microstates have signed fishing agreements with the Soviet Union. The main motive has been financial, including American unwillingness to be more generous. The Soviet ability to wage diplomacy by fishing in troubled waters has been constrained by the local South Pacific states who have only signed short-term agreements with restricted access for Soviet personnel.

The Soviet Union did not renew its fishing arrangement with Kiribati for the same reason that it sought to do so with Vanuatu--the economics of the accord. But Papua New Guinea does attract more Soviet interest; offers to take Papuan students and develop mining technology or the fishing industry are all potentially useful tools of Soviet diplomacy ${ }^{69}$. But as a new observer in ASEAN, Papua New Guinea is searching for a new international role and thus is a relatively special case offering some prospects for Soviet foreign policy.

The Soviet Union is also developing its maritime mining capability to extend its presence in the vast Pacific waters. A marine technology institute was opened in Vladivostok in March 1988 and the Soviet Union began to take advantage of its rights under the United Nations Conference on the Law of 
the Sea (UNCLOS) to explore for minerals. Its designated territory between Hawaï and Central America is being explored for iron-manganese nodules with the hope of processing up to one million tons per year. Further talks have been held with other interested Pacific maritime nations, most notably Malaysia ${ }^{70}$ and Soviet success in exploitation of the mineral resources may well bring it new partners given the Pacific's focus on maritime issues.

The Soviet Union is under no illusion that it can establish many beachheads in the "American lake". The signing of treaties on nuclear-free zones, such as the Raratonga agreement in the South Pacific, will win some friends in the region and undoubtedly antagonize the Western powers, but the Pacific beyond the coast of East Asia is not a zone of Soviet priority.

\section{CTHE SOVIET UNION'S PACIFIC IN THE TWENTY-FIRST CENTURY}

Even if the scenario described in the introduction comes to pass, from the Soviet point of view there will still be much that is unsatisfactory about the Pacific Century. First, even if the Soviet economy is booming, it is still likely to be smaller than Japan's and will be, at best, a medium-sized Pacific economy. With a sparse population and dependence on raw material exports, the Soviet economy will be as unbalanced as Japan's (albeit a mirror image).

Second, even if the United States is a declining superpower, it will remain more important to more Pacific states than the Soviet Union. U.S. security commitments will extend across the Pacific to the coast of East Asia and U.S. trade relations will weave closer webs of interdependence throughout the Pacific. The United States will focus on the Pacific, while the Soviet Union will focus on East Asia. 
Third, even if China is now more friendly to the Soviet Union than at any time in the past 30 years, China and the Soviet Union will continue to perceive each other as potentially major threats. Cooperation will increase, but competition will remain. The two social systems will survive as distinctly different varieties of Communism.

Fourth, even if Japan does become a major investor in Soviet Pacific territory and a major trade partner, it will remain primarily tied to the global market economy. Even if Japan grows more independent, it will always remain suspicious of the Soviet Union and will continue to perceive Soviet military power as a major threat.

Fifth, even if a greater spirit of community can be built among the Communist states of the Pacific, there will be severe limits to cooperation. These Pacific Communist states will also remain poorer than their non-Communist neighbours and therefore will continue to be a drain on the Soviet Union.

Finally, even if the non-Communist states in the Pacific establish closer political and economic ties with the Soviet Union, few will find the Soviet Union a replacement for their basic orientation to the Western camp. Although they will be more pragmatic and often diverse in their dealings with the Soviet Union, the USSR will have little reason or opportunity to establish close relations with the poorer of these states or the wealthier ones such as Australia, New Zealand and Canada.

Yet these obvious difficulties should not create undue pessimism about the Soviet role in the Pacific. Many of these reforms are already underway and if only half of the planned changes occur, the impact on the region will be profound. In many respects, the Soviet position in 1989 is better than at any stage since the end of the Second World War. The 
transformation of the Soviet Union into a more genuine power in the Pacific will also make it more normal, but whether normal also means more peaceful, depends to a large degree on the policies of the other states in the region. There is some prospect that a Soviet Union less concerned about military force in the Pacific and possessing a modest but effective economic role, will become an Australia with nuclear weapons. The USSR seems to have recognized that its past strategies regarding the Pacific have been inappropriate and that the region cannot be manipulated by the Soviet Union. The Pacific states may also have begun to realize this. Yet if they are seriously considering greater cooperation in the twenty-first century, it cannot be accomplished without assigning a major role to the Soviet Union.

\section{NOTES}

1. This paper was prepared under funding from IDA's Central Research Program.

2. For pre-Vladivostok analyses see Donald Zagoria, ed., Soviet Policy in East Asia (London : Yale University Press, 1982), Georges Tan Eng Bok, The ISSR in East Asia (Paris : Atlantic Institute Papers $n^{\circ}$. 59-60, 1986) and the more up-beat Gerald Segal, ed., The Soviet Union in East Asia (London : Heinemann, for the Royal Institute of International Affairs, 1983). For conservative analyses in the early days of the post-Vladivostok era, see Richard Solomon and Masataka Kosaka, eds., The Soviet Far East Military Buildup (London : Croom Helm, 1986) and Robert O'Neill, ed., East Asia, the West and International Security (London : Macmillan, 1987). For more innovative analyses sce Tsuyoshi Hasegawa, ed., The Soviet Union Faces Asia (Sapporo : Slavic Research Center, 1987) and Lawrence Grinter and Young Whan Kihl, East Asian Conflict Zones (London: Macmillan, 1988). 
3. Moscow World Service, 28 February 1988, in Foreign Broadcast Information Service, Soviet Union Report (FBIS-SOV) - 88-041, pp. 13-14.

4. Reports in BBC, Summary of World Broadcasts, SU/W0020, p. A2, and SU/W0021, p. A8. Hereafter, SU refers to the Soviet Union volume and FE refers to the Far East volume.

5. Financial Times, 27 August 1987 and Far Eastern Economic Review, 10 September 1987.

6. On these issues see Hiroshi Kimura, "Gorbachev and the Pacific", The Pacific Review, Vol. 1, No. 3, 1988.

7. Aleksandr Bogomolov, "Problems of Cooperation in the Pacific Region", International Affairs, No. 1, 1987 and "Evolution of Pacific Cooperation Ideas", Far Eastern Affairs, No. 1, 1987. See also A. Berenzov, "Multinational Companies of Hong Kong, Taiwan and South Korea", Far Eastern Affairs, No. 1, 1983.

8. Steven Levine, "Sino-Soviet Relations in the late 1980", in Grinter and Young East Asian Conflict Zones and Jonathan Pollack, "China's relations with East Asia and the Pacific", in O'Neill, ed., East Asia.

9. John Stephan and V.P. Chichkanov, eds., Soviet-American Horizons on the Pacific (Honolulu : University of Hawaii Press, 1986).

10. TASS, 30 August 1987 in SU/8664, p. A3/3; TASS, 11 September 1987 in SU/0137, p. i; and TASS, 25-26 April 1988 in SU/W0020, p. A14.

11. Moscow World Service, 13 March 1988 in SU/W0017, p. A12; and TASS, 7 February 1988 in SU/W0012, p. A10.

12. Gerad Segal, "Sino-Soviet Arms Control", in Gerald Segal, ed., Arms Control in Asia (London: Macmillan, 1987).

13. Soviet naval activity during the first half of 1988 was estimated to be down by as much as 50 percent. See Francis Fukayama, Soviet Civil- 
Military Relations and the Power Projection Mission (Santa Monica: Rand Corporation, April 1987). See also International Herald Tribune, 23 October 1987 and 13 April 1988.

14. For example, see R.A. Wolf, Change in the Soviet Far East Forces Command (Royal Military Academy Sandhurst : Soviet Studies Research Centre, May 1987).

15. Gorbachev to Merdeka, 23 July 1987 in SU/8628, pp. A3/1-9 and Soviet TV on 8 August 1987 in SU/8644, pp. A3/1-9. On arms control in Asia generally and the new Soviet position see Segal, ed., Arms Control.

16. Discussed in Far Eastern Economic Review, 3 March 1988.

17. For background see Gerald Segal, Sino-Soviet Relations After Mao (London : IISS, Adelphi Paper No. 202, 1985), "Sino-Soviet Detente", The World Today, May 1987 "Taking Sino-Soviet Detente Seriously", The Washington Quarterly, May 1989, and Tom Hart, Sino-Soviet Relations (London: Gower, 1987).

18. On 6 November 1987, Dobrynin, the Soviet Party's chief foreign policy advisor, received the head of the Chinese delegation celebrating the Seventieth anniversary of the Soviet revolution. They discussed the CCP's 13 th Congress and reform socialism, and Dobrynin drew attention to Gorbachev's greeting to Zhao Ziyang on his election to the top Party post at the Congress, while wishing success to Chinese communists. The People's Daily published Gorbachev's greeting and the text of the Central Chinese communists. The People's Daily published Gorbachev's greeting and the text of the Central Committee report was made available by the Chinese in Russian. Zhao had an article published in Kommunist, the top Soviet Party Journal, in January. See SU/0078, p. A3/5 and SU/8720, p. C14.

19. See note 2, but also the statement from Defence Minister Yazov, 22 February 1988 in SU/0083, pp. C5-6.

20. China slipped back to fourth place in 1987 because of dislocation caused by Soviet and Chinese internal restructuring. Details and 
discussion of the problems are in SU/W0022, p. A1, and "China : Economic Politics and Performance in 1987" ClA Report to the Subcommittee on National Security of the JEC, 21 April 1987. The planned trade target for 1990 will not be met according to Soviet sources. Sotsialisticheskaya industriya, 7 May 1988, in SU/W0026, p. A1.

21. The Economist, 12 September 1987.

22. Bulgarian interview with the Soviet Deputy Foreign Minister Rogachev, 18 February 1988 in SU/0094, p. A3/1.

23. 21 December 1987 in FE/0034, p. A2/1.

24. Gerarld Segal, "The USSR and China in 1988", Asian Survey, January 1989.

25. Segal, The Washington Quarterly, May 1989.

26. Gilbert Rozman, A Mirror for Socialism (London : I.B. Tauris, 1985) and The Chinese Debate About Soviet Socialism (London : I.B. Tauris, 1987).

27. For a clear Soviet statement of this line see E. Bazhanov, "Shift of Emphases", New Times, No. 17 and 18, 1988.

28. People's Daily, 18 May 1988, in FE/0160, pp. A2/1-2.

29. 5 December in SU/0028, p. A3/1 and 15 January 1988 in FE/0080, p. $\mathrm{A} 2 / 1$ and $\mathrm{SU} / 0052$, p. i.

30. Michael Kaser, "Soviet and Chinese Economic Reforms", The Pacific Review, Vol. 1, No. 1, 1988.

31. Xinhua, 20 March 1988 in FE/0107, p. A2/1.

32. V. Dashichev in Literaturnaya gazeta, 18 May 1988, in SU/0157, pp. C1/1-5.

33. See a Chinese assessment of 6 May 1988 in FE/0145, p. i. 
34. 29 November 1987 in SU/0018, p. A3/2; 3 December in FE/0022, p. $\mathrm{A} 2 / 1 ; 21$ December in FE/0039, p. A2/1; 12 January in FE/0055, p. A2/1; 17 January in FE/0052, p. A2/1; 8 February in FE/0072, p. A2/1; and TASS, 11 March in SU/W0017, p. A12. See also Moscow World Service, 25 February 1988 in FBIS-SOV-88-041, pp. 14-15.

35. See the Discriminate Deterrence report and also FE/0038, p. A1/1, and Far Eastern Economic Review, 24 March 1988, p. 19.

36. International Herald Tribune, 16 May 1988.

37. International Herald Tribune, 26 May 1988.

38. International Herald Tribune, 28 March 1989.

39. Far Eastern Economic Review, 7 January 1988.

40. Paul Dibb, The Soviet Union : The Incomplete Superpower (London : Macmillan, 1986).

41. Gerald Segal, "Pragmatic Politics", SAIS Review, Vol. 7, No. 2, 1987.

42. Nigel Harris, The End of the Third World (London: Penguin, 1987).

43. Far Eastern Economic Review, 3 March 1988.

44. Prime Minister Ryzhkov statement on 27 January 1988 in SU/0069, p. A3/6.

45. See, for example, the signs of cooperation between the Soviet Union, China, Mongolia and North Korea on railway links, 1 March 1988 in FE/0091, p. i.

46. TASS, 27 January 1988 and Kyodo, 1 February 1988 in SU/0069, p. $\mathrm{A} 3 / 6$.

47. TASS reports of 20, 27 and 28 March 1988 in SU/W0019, p. A1 and SU/W0018, p. A2; and 30 April and 1 May in SU/W0025, p. A2. 
48. 25 March in SU/0017, pp. A3/1-2 and Kumao Kaneko, "A New Pacific Initiative", Japan Review of International Affairs, Vol. 2, No. $1,1988$.

49. See the interview with Y. Primakov in New Times, No. 19, 1988.

50. Not including USSR, to 8 Europe and 7 in Asia : Mongolia, North Korea, China, Vietnam, Laos, Kampuchea, Afghanistan.

51. Alan Sanders, "Mongolia and Sino-Soviet Relations", The Pacific Review, Vol. 1, No. 2, 1988.

52. Far Eastern Economic Review, 17 March 1988.

53. Moscow Home Service, 22 June 1987 in SU/8602, p. C2/1; Hanoi Home Service, 20 October 1987 in FE/8706, p. A2/1-3; Sotsialisticheskaya industriya, 23 March 1988 in FE/0110, p. A2/1 and The Financial Times, 19 January 1988.

54. Vietnamese News Agency, 14 January 1988 in FE/0052, p. A2/1.

55. Hanoi Home Service, 17 March 1988 in FE/0105, p. A2/2.

56. Far Eastern Economic Review, 25 February 1988.

57. Radio Liberty, No. 356/87, 24 August 1987 and Far Eastern Economic Review, 18 June 1987.

58. Ekonomicheskaya gazeta, No. 11, 1988 in FBIS-SOV-88-057, p. 15.

59. Sce Soviet comments during the visit of the North Korean Foreign Minsiter on 29 April 1988 in SU/0141, p. A3/1.

60. M. Ukraintsev, "The Soviet Union's Growing Cooperation with Asian Socialist Nations and Kampuchea", Far Eastern Affairs, No. 1,1986 .

61. A March 1988 accord was noted in FE/W0017, p. i.

62. Far Eastern Economic Review, 3 March 1988. 
63. Pravda, 16 March 1988 in FE/0105, p. A2/1 and AFP, 16 February in FE/0078, p. i.

64. Pravda, 19 March 1988 in SU/0106, p. A3/1.

65. Details in China News Agency, 8 March 1988 in FE/0095, p. i; Xinhua, 25 February 1988 in FE/0094, p. A2/2, FE/W0022, p. i and FE/W0020, p. A13; Far Eastern Economic Review, 3 March and 14 April 1988, and Financial Times, 5 March 1988.

66. Moscow World Service, 27 April 1988 in SU/W0024, p. A2 and Financial Times, 5 March 1988.

67. For example, Mahathir's visit to Moscow in July 1987 in SU/8636, pp. A3/1-8 or Deputy Foreign Minister Rogachev's month-long trip to southeast Asia in April 1988. See FE/0122, p. 3. The Thai Prime Minister was in Moscow in May 1988, see SU/0156, pp. A3/1-4.

68. July 1987 on Mahathir's visit in FE/8636, p. A2/2.

69. Radio Australia, 2 March 1988 in FE/0094, p. A2/1.

70. Moscow World Service, 13 March 1988 in SU/W0017, p. A12; TASS, 7 February in SU/W0012, p. A10; Moscow Radio, 1 March in SU/W0016, p. A16 and 25 February in SU/0101, p. A3/2. 


\section{RESUME}

La nouvelle orientation prise par l'URSS à l'égard de la région de l'Asie Pacifique, due principalement au retard croissant de l'Extrême-Orient soviétique, est antérieure au discours prononcé à Vladivostok en juillet 1986 par M. Michel Gorbatchev.

Pour atteindre son objectif, soit participer pleinement à toutes les organisations du bassin du Pacifique, l'URSS cherche à minimiser l'influence des Etats-Unis dans la région et à exploiter les convergences d'intérêts avec la République populaire de Chine; elle traitera désormais le Japon sur un pied d'égalité et incitera les Etats socialistes qui lui sont alliés à plus de rigueur économique.

En Asie orientale, l'URSS compte développer la coopération et les échanges avec les économies nouvellement industrialisées mais dans la zone plus large de l'Océan Pacifique tout entier, l'URSS ne recherche pas vraiment à affirmer sa présence. Les matières premières qui constituent ses seuls produits exportables ne trouvent pas preneurs et les Etats du Pacifique ne se prêtent guère à une exploitation politique; la seule exception possible étant la Nouvelle-Guinée-Papouasie en quête d'un rôle international.

Même si les réformes soviétiques étaient couronnées de succès rapides, l'Union Soviétique sera toujours au 21ème siècle une économie moins développée que celle des voisins à économie de marché; tout au plus pourra-t-elle représenter l'équivalent d'une Australie mais dotée d'engins nucléaires. Elle ne pourra en aucun cas remplacer les Etats-Unis et leurs alliés dans la région. 